\title{
Thymus-derived lymphocyte enumeration in patients with uveal malignant melanoma
}

\author{
NORMAN T. FELBERG' AND JERRY A. SHIELDS? \\ From the 'Department of Molecular Biology of the Research Division and the \\ 'Oncology Service, Wills Eye Hospital, and the ''Department of Ophthalmology and the \\ 'Department of Biochemistry (NTF) of the Jefferson Medical College, Thomas Jefferson University, \\ Philadelphia, USA
}

SUMmaRY Thymus-derived lymphocytes (T lymphocytes) were enumerated in patients with uveal malignant melanoma. Two T-lymphocyte subpopulations were determined, the active rosette forming cells (A-RFC) and the total rosette forming cells (T-RFC). Subjects were divided into the following groups: $(a)$ pretreatment patients, $(b)$ patients treated by enucleation, $(c)$ patients treated by photocoagulation, $(d)$ patients treated by cobalt plaque radiotherapy, $(e)$ patients treated by enucleation who developed clinically detectable metastasis, and $(f)$ normal controls. There were no differences in the numbers of A-RFC or T-RFC in the control population, pretreatment patients, and those treated in the different ways. Statistically significant depressions of A-RFC and T-RFC levels were seen in patients with metastatic lesions, suggesting that they had an impairment of immunocompetence, as measured by T-lymphocyte rosette formation.

Immune surveillance of solid tumours is generally accepted to be a function of the cell-mediated immune system. The ability of malignant cells to escape surveillance has been postulated to be due to a number of mechanisms such as the 'shedding' of tumour antigens or of other tumour products which can cause the suppression of the host's immune system.' Cell-mediated immune responses have been demonstrated by in-vitro and in-vivo methods in patients with uveal malignant melanoma..$^{23}$

In this study active rosette forming cells (A-RFC) and total rosette forming cells (T-RFC) were enumerated as a measure of cell-mediated immunity because they are reported to correlate well with cellmediated immunity. ${ }^{4}$ A-RFC represent a special subset of $\mathrm{T}$ lymphocytes that have a higher affinity for sheep erythrocytes (E) and have a more consistent relationship to active immunity than do T-RFC. ${ }^{5}$ A-RFC probably represent 'activated' $T$ lymphocytes, which are involved in ongoing immune responses. ${ }^{4}$

Correspondence to Norman T. Felberg, PhD, Rescarch Division, Wills Eyc Hospital, 9th \& Walnut Strects, Philadelphia, PA 19107, USA.

\section{Patients and methods}

Patients. Eighty patients with the clinical diagnosis of uveal malignant melanoma who had not been treated were examined at the Oncology Service of the Wills Eye Hospital by one of the authors (J.A.S.) between 1977 and 1979. Therapy was provided according to established procedures." T lymphocytes were enumerated on these 80 patients. A post-therapy group consisted of the 80 pretreatment patients and an additional 24 patients who had their A-RFC and T-RFC evaluated after therapy. The patients in the post-therapy group included 62 patients who had been treated by enucleation, 15 patients treated by photocoagulation, and 27 patients treated by cobalt 60 plaque radiotherapy. ${ }^{7}$ During follow-up nine of the patients treated by enucleation developed metastasis confirmed either by biopsy, liver and bone scans, or necropsy. Patients receiving immunotherapy or chemotherapy were not included in this study. Normal controls consisted of 100 employees and volunteers without apparent disease or immunological depression.

Lymphocyte preparation. Ethylenediamine tetraacetic acid (EDTA) anticoagulated blood was 
separated on a Ficoll-hypaque discontinuous gradient. The lymphocyte layer was washed to remove thrombocytes. Viability by trypan blue exclusion was usually greater than $95 \%$. Purity determined after Wright's staining indicated that more than $95 \%$ of the cells were mononuclear leucocytes.

Rosette formation. Lymphocytes $\left(0 \cdot 1 \mathrm{ml}\right.$ of $5 \times 10^{\circ}$ cells/ml of Hanks's balanced salt solution, HBSS) was mixed in a $12 \times 75 \mathrm{~mm}$ snap-cap plastic tube with an equal volume of sheep $E(0 \cdot 05 \%)$ and $20 \mu \mathrm{l}$ of absorbed normal human serum. After 5 minutes at $37^{\circ} \mathrm{C}$ the tube was centrifuged at $100 \mathrm{~g}$ for 5 minutes. A-RFC were determined immediately and T-RFC were determined after an additional 90-minute incubation at $4^{\circ} \mathrm{C}$ according to Wybran et al. ${ }^{8}$

Statistical comparisons. Results were compared by Student's $t$ test. Probabilities less than 0.05 were considered significant.

\section{Results}

The numbers of A-RFC and T-RFC enumerated for the pretherapy patients and the controls are presented in Table 1. Overall no statistical difference was found between the two groups. During the course of the study no significant changes in the number of rosette forming cells were found in the patients treated by enucleation, photocoagulation, or cobalt plaque irradiation (Table 2). On the other hand those nine patients who developed metastatic melanoma had significantly $(p<0.001)$ decreased levels of A-RFC and T-RFC. Serial enumerations of the two rosette forming cell populations in Fig. 1 showed decreasing levels of A-RFC and T-RFC even before the clinical detection of metastatic disease.

\section{Discussion}

The loss of immunocompetance as measured by rosette forming cells in the general circulation has been previously described in other malignancies at the time of diagnosis." "1" In this study we found no statistically significant differences in A-RFC and TRFC levels at the time of diagnosis in 80 patients with malignant melanoma of the uvea (Table 1).

Table 1 Rosette forming cells in pretherapy patients with uveal malignant melanoma and in control patients

\begin{tabular}{lcll}
\hline Diagnosis & Number & \multicolumn{2}{l}{$\%$ Rosette forming cells } \\
\cline { 3 - 4 } & & Active & Total \\
\hline Mclanoma & 80 & $24 \cdot 39 \pm 11 \cdot 48$ & $55 \cdot 84 \pm 12 \cdot 53$ \\
Controls & 100 & $24 \cdot 78 \pm 10 \cdot 66$ & $55 \cdot 89 \pm 10 \cdot 75$ \\
\hline
\end{tabular}

$\pm=$ Standard deviation.
Table 2 Rosette forming cells in patients with uveal malignant melanoma after treatment

\begin{tabular}{llll}
\hline Treatment & Number & \multicolumn{2}{l}{$\%$ Rosette forming cells } \\
\cline { 2 - 4 } & & Active & Total \\
\hline Enuclcation & 62 & $22 \cdot 82 \pm 10 \cdot 13$ & $52 \cdot 45 \pm 12 \cdot 35$ \\
Phocoagulation & 15 & $20.53 \pm 11 \cdot 54$ & $53 \cdot 80 \pm 7 \cdot 86$ \\
Cobalt plaque & 27 & $22 \cdot 56 \pm 11 \cdot 84$ & $53 \cdot 93 \pm 12 \cdot(0)$ \\
\hline
\end{tabular}

Values indicate the average and one standard deviation of the most recent follow-up data for cach patient.

Recently several authors have suggested that an increased mortality rate following enucleation may be due to several possible mechanisms, including tumour dispersion during surgery, enucleation selectively given to those patients with large or rapidly growing tumours, or immunosuppression following surgery and anaesthetic. ${ }^{11-14}$ To assess the immunocompetance of patients after therapy for their uveal malignant melanoma we compared the numbers of A-RFC and T-RFC in patients treated in different ways. We could find no differences in the numbers of A-RFC or T-RFC in the patients treated by enucleation photocoagulation or cobalt plaque irradiation (Table 2). Our results suggest that, if indeed these forms of therapy can induce an immunosuppression, it does not appear to be detectable with assays such as A-RFC or T-RFC enumeration.

Metastasis in other cancers has been associated with immunosuppression related to depressed numbers of rosette forming cells. ${ }^{15}$ Our study extends these observations to uveal malignant melanoma. We have detected depressed numbers of A-RFC and T-RFC as much as three months prior to the clinical detection of or death due to metastasis (Table 3, Fig. 1). In addition decreased $T$ cells have been reported in patients with systemic metastases from uveal melanoma by a different rosetting technique. ${ }^{10}$

From the results of our study we do not believe that there is any diagnostic value in enumerating A-RFC and T-RFC lymphocytes in the initial evaluation of patients with uveal malignant melanoma. A-RFC and

Table 3 Rosette forming cells in patients with metastasis from uveal malignant melanoma

\begin{tabular}{lcll}
\hline Diagnosis & Number & \multicolumn{2}{l}{$\%$ Rosette forming cells } \\
\cline { 3 - 4 } & & Active & Total \\
\hline Mclanoma & $9^{*}$ & $14 \cdot 22 \pm 5 \cdot 79 \dagger$ & $39 \cdot 89 \pm 11 \cdot 23+$ \\
Control & $1(0)$ & $24 \cdot 78 \pm 10 \cdot 66$ & $55 \cdot 89 \pm 10 \cdot 75$ \\
\hline
\end{tabular}

* Rosette forming cells were assayed $3.11 \pm 3.49$ months prior to the clinical detection of metastasis or death.

$t p<() \cdot()(0) 1$ compared with controls or pretherapy patients. 


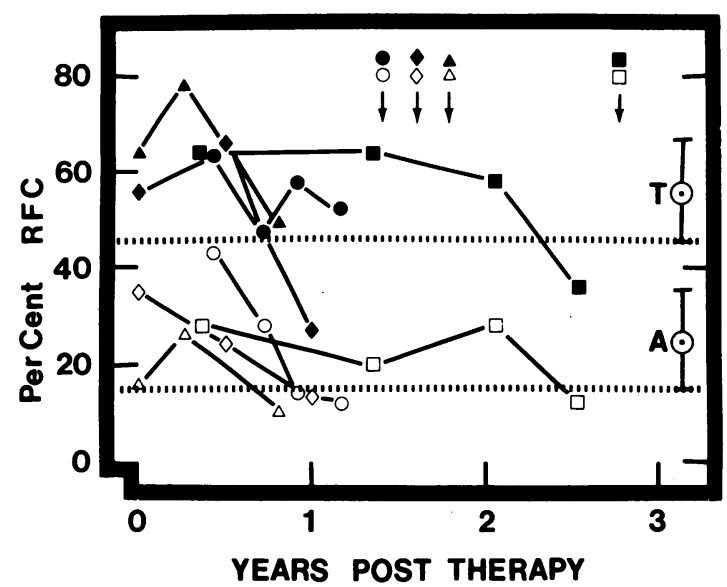

Fig. 1 Serial Tlymphocyte levels of four patients with uveal malignant melanoma treated by enucleation at time zero. Total rosette forming cells $(T-R F C)$ are represented by solid symbols. The average and I standard deviation from the mean for 100 normal volunteers is seen to the right $(\mathrm{T})$. Active rosette forming cells $(A-R F C)$ are represented by open symbols. The average and I standard deviation from the mean for 100 normal volunteers is seen to the right (A). $T-R F C$ and A-RFClevels below their respective dashed lines are considered depressed. Symbols at the top of the Figure indicate when the patient died of metastatic disease.

T-RFC enumeration may have some prognostic value, since depression can occur many months before the clinical detection of metastatic disease. Functional lymphocyte tests, such as lymphoblast transformation, ${ }^{1718}$ may be more sensitive than A-RFC and T-RFC enumeration as a measure of immunocompetance, while other laboratory adjuncts that do not depend on host immunocompetance, such as serum gamma-glutamyl transpeptidase, ${ }^{19}$ may be more sensitive than rosette formation in detecting metastasis.

The authors thank James Augsburger, MD, for his helpful discussion of this study.

This work was supported in part by the Pennsylvania Lions Sight Conservation and Eyc Rescarch Foundation, Inc., NIH grant EY 04125 (Dr Felberg), and NIH grant EY (04041 and the Ocular Oncology Fund, Wills Eyc Hospital (Dr Shiclds).

\section{References}

1 Curric G. Malignant discasc. In: Holborow EJ, Recves WG, cds. Immunology in medicine. New York: Grunc and Stratton, 1977.

2 Char DH, Hollinshead A. Herberman RB. Skin tests with soluble melanoma antigens in patients with choroidal tumors. Cancer 1977; 40: 165()-4.

3 Hollinshcad AC, Herberman RB, Jaffurs WJ, Alpert LK, Minton JP, Harris JE. Soluble membrane antigens of human malignant mclanoma cells. Cancer 1974; 34: 1235-43.

4 Traycoff RB, Wortsman J, Mycrs WL, Rogers W. The significance of the active E-rosette forming cell. Clin Immunol Immunopathol 1979; 13: 383-93.

5 Felsburg PJ, Edclman R. The active E-rosette test: a sensitive in vitro correlate for human delayed-type hypersensitivity. $J$ Immunol 1977; 118: 62-6.

6 Shiclds JA. The management of posterior uveal melanomas. The diagnosis and management of intraocular tumors. St Louis: Mosby, 1983: chapter 10.

7 Shiclds JA, Augsburger, JJ, Brady LW. Day JL. Cobalt plaque therapy of postcrior uvcal melanoma. Ophthalmology 1982; 89: 1201-7.

8 Wybran J, Chantler S. Fudenberg HH. Isolation of normal T cclls in chronic lymphatic leukemia. Lancet 1973; i: 126-9.

9 Wybran J, Fudenberg HH. Thymus-derived rosettc-forming cells in various human discase states-cancer, lymphoma, bacterial and viral infections and other discases. $J$ Clin Invest 1973; 52: 1026-32.

10) Fuks Z, Strober S, Kaplan HS. Interaction between serum factors and T lymphocytes in Hodgkin's discase. N Engl J Med 1976; 295: 1273-8.

11 Zimmerman LE, McLcan IW, Foster WD. Does enucleation of the cye containing malignant melanoma prevent or accelerate the disscmination of tumour cells? Br J Ophthalmol 1978; 62: 420)-5.

12 Wilson RS, Fraunfelder FT. 'No-touch' cryosurgical enucleation. A minimal trauma technique for cyes harboring intraocular malignancy. Opthalmology 1978; 85: 1170-5.

13 Boniuk M. Editorial. A crisis in the management of patients with choroidal mclanoma. Am J Ophthalmol 1979; 87: 840-2.

14 Jakobicc FA. Editorial. A moratorium on enucleation for choroidal mclanoma. Ain J Ophthalmol 1979; 87: 842-6.

15 Decgan MJ, Coulthard SW. Spontancous rosettc formation and roscttc inhibition assay in patients with squamous cell carcinoma of the head and neck. Cancer 1977; 39: 2137-41.

16 Char DH. Immunological mechanisms in choroidal melanoma. Trans Ophthalmol Soc UK 1977; 97: 389-93.

17 Sunba MSN, Rahi AHS, Morgan G, Holborow EJ. Lymphoproliferative response as an index of cellular immunity in malignant melanoma of the uvca and its correlation with the histological features of the tumour. Br J Ophthalmol 1980); 64: 576-9).

18 Priluck IA, Robertson DM, Pritchard DJ, Ilstrup DM. Immune responsiveness in patients with choroidal malignant melanoma. Am J Ophthalmol 1979; 87: 215-20.

19 Fclberg NT, Shiclds JA, Maguire J, Pipcrata S, Amscl J. Gamma-glutamyl transpeptidase in the prognosis of paticnts with uvcal malignant melanoma. Ain J Ophthalmol 1983; 95: 467-73. 